\title{
Cobras, xamãs e caçadores entre os Katukina (pano)*
}

\section{Snakes, shamans and hunters among the Katukina (pano)}

\author{
Edilene Coffaci de Lima**
}

\begin{abstract}
Resumo: Neste artigo ensaio uma reflexão sobre a oposição entre caçadores examãs entre os Katukina, falantes de uma língua pano, moradores de duas terras indígenas localizadas no Acre. É amplamente sabido e discutido na literatura etnológica amazônica que caçadores e xamãs se opõem. Sem divergir dessa interpretação, sustentarei que, ao menos entre os Katukina, seus conhecimentos específicos provêm igualmente de uma mesma fonte: das grandes cobras, moradoras das profundezas das águas. Para sustentar meu argumento, ainda que sem pretensão de ser exaustiva, servir-me-ei da literatura pano, abundantemente desenvolvida nas duas últimas décadas, na tentativa de estabelecer comparações que indiquem as possíveis similitudes e, concomitantemente, as elaborações diferenciais desse tema que é comum entre os falantes de língua pano no sudoeste amazônico.
\end{abstract}

Palavras-chave: Katukina; xamanismo; caça

Abstract. In this article I present reflections on the opposition between hunters and shamans among the Katukina, speakers of a pano language, dwellers in two indigenous areas located in Acre. It is widely known and discussed in the ethnological literature of Amazonas that hunters and shamans are opposites. Without diverging from this interpretation, I will support that, at least among the Katukina, their specific knowledge comes for both from the same source: the great snakes, dwellers in the depths of the waters. To support my argument, without the expectation of being exhaustive, I will use the pano literature, abundantly developed in the last two decades, in the attempt to establish comparisons which indicate the possible similarities and at the same time, the differentiating elaborations of this theme which is common amongst the speakers of the pano language in southwest Amazonas.

Key words: Katukina; shamanism; hunting.

\footnotetext{
* O que vai aqui escrito consta, agora com algumas revisões e acréscimos, da

* O que vai aqui escrito consta, agora com algumas revisões e acréscimos, da
última seção do quinto capítulo de minha tese de doutorado defendida, em 2000, no PPGAS da USP.
}

** Mestre e Doutora em Antropologia pela Universidade de São Paulo. Desde 1996 é professora do Departamento de Antropologia e do Programa de PósGraduação em Antropologia Social da UFPR. edilima@uol.com.br 
Neste artigo ensaio uma reflexão sobre a oposição entre caçadores e xamãs entre os Katukina, falantes de uma língua pano, moradores de duas terras indígenas localizadas no Acre ${ }^{1}$. É amplamente sabido e discutido na literatura etnológica que caçadores e xamãs se opõem - entre os povos de língua pano, ver Deshayes (1992) e Townsley (1993). Sem divergir dessa interpretação, sustentarei que, ao menos entre os Katukina, seus conhecimentos específicos provêm igualmente de uma mesma fonte: das grandes cobras (boídeos) moradoras das profundezas das águas. De saída, apresento dois mitos katukina que fundamentam a vinculação dos conhecimentos cinegéticos e xamânicos à mesma origem. Em seguida, abordo outras práticas relacionadas às rotinas de caçadores e xamãs, que acabam por contrastá-los. Por fim, trato dos processos de aquisição e transmissão desses conhecimentos, que me permitem aproximálos novamente. Para sustentar meu argumento, ainda que sem pretensão de ser exaustiva, servir-me-ei da literatura pano, abundantemente desenvolvida nas duas últimas décadas, na tentativa de estabelecer comparações que indiquem as possíveis similitudes e, concomitantemente, as elaborações diferenciais desse tema que é comum entre os falantes de língua pano no sudoeste amazônico.

Como já há algum tempo observou Philippe Erikson (1998, p.51), os grupos de língua pano chamam a atenção pelo contraste derrotante entre sua unidade manifesta em escala global e a extrema atomização que os caracterizam no plano local. Como o autor escrevera no mesmo artigo, abundam entre os panos "traços" comuns, alguns dos quais serão aqui mencionados, como o uso de estimulantes cinegéticos, particularmente da secreção do kampô (Phyllomedusa bicolor), na caça; e do tabaco, no lugar da ayahuasca, no xamanismo. A literatura pano avolumou-se bastante nos últimos anos, e a compreensão da atomização dos povos de língua pano tem encontrado em inúmeras etnografias - e no diálogo entre colegas - tentativas de compreensão desse conjunto no qual a cada vez que se lê um novo trabalho, seja sempre inevitável, de certa forma paradoxalmente, continuar a se surpreender com a impressão de que os pano são, a um só tempo, tão diferentes e tão parecidos entre si. Tudo se passa como se houvesse mesmo um repertório de temas e questões no qual pendem em diferentes direções, imprimindo transformações quando se desloca através das frágeis linhas demarcatórias. Até pouco tempo atrás ${ }^{2}$, a labilidade dessas fronteiras étnicas, parece ter permitido sedimentar a impressão, vivamente destacada por Erikson (idem, p.51), de que os povos de língua pano "se dividem para melhor reinar". 


\section{A cobra grande para xamãs e caçadores}

Entre nós é bastante conhecido o temor que as cobras despertam. Apenas a título de ilustração, na tradição judaico-cristã, a cobra é tida "como o mais astuto dos animais" (Gênesis, 2,3). Mundkur (1976), um biólogo que fez um exaustivo estudo sobre as representações acerca da cobra em diferentes culturas, sustenta que ela é o mais poderoso dos símbolos animais, devido ao "poder de seu veneno". Na abordagem neodarwinista de Mundkur, os sentimentos de temor e, ao mesmo tempo, fascínio que as cobras despertam estão geneticamente inscritos na fisiologia dos homens (e dos primatas), resquícios adaptativos de nossos ancestrais, que teriam tido nas cobras seus adversários mais temidos.

Esta generalização, por certo apressada, não passou despercebida na literatura antropológica. Lee Drummond (1981), um antropólogo também interessado no simbolismo das serpentes, foi um dos primeiros a contestar as afirmações de Mundkur. Drummond argumentou que Mundkur, estranhamente, parece ter se esquecido de observar as anotações sobre as inúmeras cobras não-venenosas, principalmente boídeos e pítons, que constam em seu próprio inventário sobre o "culto da serpente".

As informações de que disponho sobre as serpentes entre os Katukina permitem a mesma contestação. Ainda que haja um interesse bem marcado por todas as cobras, particularmente pelos desenhos labirínticos de sua pele, a maior parte desse interesse recai sobre espécies não-peconhentas, em particular sobre os boídeos. Se fosse para escalonar o lugar que as diferentes espécies animais ocupam nos mitos katukina, certamente as cobras não-venenosas de grande porte, terrestres ou aquáticas, ocupariam o topo.

As grandes cobras ocupam um lugar central nas narrativas míticas katukina. Em primeiro lugar, e de modo saliente, a troca periódica de pele das cobras é interpretada como indício de sua imortalidade e fazem-nas prototípicas da vida eterna que, aliás, alcançaram por distração ou descuido dos próprios Katukina, que a perderam, como se pode entender na narrativa que me foi contada, repetidas vezes, por diferentes pessoas e que reproduzo abaixo:

Logo que nós surgimos, outros nawa gritaram:

- "Como é que vocês vão viver daqui pra frente?"

Os nawa tinham a pedra do céu e um deles falou:

- "Vem pegar essa pedra, para vocês não morrerem."

E ninguém foi buscar essa pedra. O nawa gritou de novo. Nós respondemos: 
- “O que é?"

E o nawa gritou de novo... Os Katukina mandaram um menino pequeno ir buscar esta pedra. Quando o menino chegou lá onde os outros nawa estavam e aquele que tinha chamado falou que não daria a pedra para o menino, porque ele era pequeno e poderia jogar a pedra dentro d'água. Então o nawa falou:

- "Já que vocês perderam a minha pedra... Eu queria dar a pedra para vocês, mas perderam [a oportunidade de ter] a minha pedra. Agora vocês não vão ser muitos, porque a minha pedra ia ajudar a aumentar a população de vocês. Mas vocês já perderam... Agora, quando um morre, outro nasce, assim vocês vão viver a vida inteira e não vai aumentar a população de vocês."

Aí quem pegou essa pedra foi o calango, a cobra, o mulateiro. Por isso que a cobra, o calango e o mulateiro não morrem, somente trocam a pele. Como nós não pegamos essa pedra, a gente morre. Se tivéssemos pego esta pedra, a gente ficava bem velhinho, trocava o cabelo, a pele e ficava novo.

As cobras, os calangos e o mulateiro trocam a pele de tempos em tempos e têm então uma renovação periódica da vida. Entre os homens, a flacidez e o enrugamento da pele, o embranquecimento dos cabelos e a perda do vigor físico estão aí para lembrar a incontornável finitude do ser.

Imortais por deterem a "pedra" que garante a vida eterna, as cobras acumulam ainda a posse dos conhecimentos xamânicos. Ambas as posses estão certamente atreladas e as cobras, conhecedoras dos segredos xamânicos e da cura justamente por viverem indeterminadamente, convertem-se no foco dos interesses dos Katukina. E não se trata pura e simplesmente de uma metáfora para contrapor essas espécies privilegiadas ante a existência finita dos homens. Seja para tornar-se um xamã ou rezador ${ }^{3}$, um homem tem de passar por um contato sobrenatural com uma grande serpente que, lançando o rome em seu corpo, o capacita a ter acesso aos conhecimentos xamânicos. Justamente por deterem conhecimentos fundamentais aos homens, as cobras não são mortas pelos Katukina. Aquele que a mata ou maltrata, corre o risco de expor-se à sua vingança. Recusar seu convite é perfeitamente admissível, não o é não saber identificá-lo e agir com violência. A recusa violenta ao chamado de uma grande serpente é replicada na mesma proporção, de forma também violenta.

A jibóia é protagonista de um outro mito, agora relacionado à caça, que me foi contado por Mani:

Tinha um rapaz que era panema, muito panema mesmo. Um dia ele foi caçar e não conseguia matar nada. Ele encontrou uma cobra (mana rono, jibóia) na floresta e resolveu matá-la para comer. No caminho de 
volta anoiteceu e ele teve que dormir na floresta. Havia duas árvores: ele dormiu encostado em uma árvore e colocou a carne da cobra que carregava encostada na outra. Quando ele acordou, mexeu no paneiro onde estava a carne da cobra e ouviu um barulho. Ele pensou: Esta cobra virou o quê? A cobra tinha virado gente. Dali a pouco a cobra apareceu como um homem e falou:

- Eu vim caçando, fiquei perdido e dormi aqui.

Eles conversaram um pouco e combinaram de trocar os olhos: a cobra ficou com os olhos dele e ele ficou com os olhos da cobra. O rapaz voltou então para sua casa. Lá, ele ficava na beira do fogo e via passar muitos veados. Ele perguntava para seus parentes de quem era aquela criação de veados, mas não era de ninguém. Ele matou um veado e comeu. Depois passaram muitos porcos. Ele matou para comer a carne. A cobra havia pedido para ele não dizer para ninguém que tinha trocado os olhos com ele.

O rapaz foi tomar banho e viu criação de jacaré. Depois viu criação de queixada. Passou um pouco e já tinha uma criação de anta passando na frente dele. O tempo passou e ele continuava vendo todos os bichos e matando-os com facilidade.

Um certo dia ele estava bêbado de caiçuma (atsa katxa) e alguém lhe perguntou por que via as coisas assim, por que é que tantos bichos passavam sob a sua visão. Ele estava bêbado e contou que tinha trocado os olhos com a cobra. Passado um tempo, ele foi no mato mijar e a cobra apareceu e falou:

- Eu disse para você não falar para ninguém que trocou os olhos comigo.

Então eles destrocaram os olhos - ele ficou com seu próprio olho e a cobra com o dela - e o rapaz ficou panema de novo.

A visão privilegiada após trocar de olhos com uma jibóia fez com que o rapaz adotasse o ponto de vista dela. Então os bichos apareciam aos montes a seus olhos, como se fossem mansos - à sua frente passavam "criações" de veados, queixadas e jacarés -, e tornavam-se presas fáceis. Transformada a sua visão, o rapaz deixou de ser panema. Tornou-se, subitamente, um caçador bem-sucedido. Descuidado, como tantas vezes o são os personagens míticos, quebrou o segredo pactuado com a cobra e acabou retornando à sua condição original de caçador empanemado.

A associação mítica das cobras com o sucesso na caça repercute no dia-a-dia ${ }^{4}$. Os homens fazem pedidos de sorte na caça quando encontram uma cobra grande e declinam o convite implícito à carreira xamânica. Alguns encontros com cobras podem também tornar um homem panema. 
Tendo em conta os dois mitos, especialistas xamânicos e caçadores têm a eficácia de suas atividades vinculadas simbolicamente à mesma origem, às cobras grandes, terrestres e aquáticas, como se os animais estivessem todos sob sua guarda. Por inferência, parece-me perfeitamente possível conferir às cobras grandes o título de "donas" dos animais, mesmo que os Katukina jamais tenham explicitamente comentado essa possibilidade.

Arrisco esta interpretação, que restrinjo apenas aos Katukina, porque em outros grupos pano podem-se igualmente recolher informações sobre a vinculação das cobras tanto ao xamanismo quanto à caça. Às vezes, como ocorre com os Katukina, a alternância entre a vinculação das cobras com o xamanismo ou com a caça ocorre no interior do mesmo grupo; outras vezes, certas práticas relacionadas ao xamanismo em um dado grupo aparecem atreladas à caça em um outro, como se houvesse ocorrido um câmbio de posições. Vejamos.

Há bastante tempo, graças à publicação de um artigo de Tastevin (1926), sabe-se da dupla associação das cobras ao xamanismo e à caça na cosmologia kaxinawa. Nele, o missionário espiritano tanto fornece uma pequena versão da obtenção da ayahuasca por intermédio de uma cobra, que seduziu um homem para debaixo d'água, quanto descreve um rito de caça no qual os homens tocaiam e cercam uma jibóia e, apontando para as manchas de sua pele, pronunciam o nome dos animais que desejam abater. Em etnografias contemporâneas, Deshayes (1992, p.102) comentou que os homens devem chupar a língua de uma jibóia para terem sorte na caça. Numa coletânea de mitos kaxinawa (CPI-AC 1995, p.162-164), um deles destaca a vinculação entre a cobra e a caça. Por sua vez, Lagrou (1988, p.62 e 76) registrou o consumo cru da carne, língua, coração e olhos de jibóias, como parte do processo para obter os conhecimentos de caça e feitiçaria.

Enquanto entre os Yaminawa (Townsley 1988, p.133), excrementos da anaconda são consumidos para que os homens obtenham os conhecimentos xamânicos, entre os Amahuaca, os homens comem os excrementos a fim de tornarem-se bons caçadores ${ }^{5}$ (Carneiro 1970). Por sua vez, Saladin d'Anglure e Morin (1998) destacaram, entre os Shipibo-Conibo, a vinculação das cobras com os conhecimentos xamânicos, Roe (1982, p.52), em seu trabalho sobre o mesmo grupo, fornece um mito em que as cobras são vinculadas ao sucesso na caça. Neste mito, um caçador azarado encontra um homem-cobra e após este manipular e assoprar sua zarabatana, torna-se um exímio caçador. Erikson (2001), escrevendo sobre 
os Matis, associa estreitamente xamãs e usuários de zarabatanas. Em suas próprias palavras, "ambos operam por meio de pequenos dardos (visíveis ou invisíveis) e o princípio místico, sho, é o que garante eficácia tanto das zarabatanas quanto dos xamãs". A informação nada diz sobre a vinculação dos conhecimentos xamânicos e de caça às cobras, mas sugere correlações importantes entre os dois especialistas. Nesse sentido, talvez não seja mera coincidência o fato de que os Yawanawa (Pérez, 1999, p.38) designam seus cantos de cura de shuanka enquanto os Katukina chamam como shonka as antigas zarabatanas. Além da semelhança, os dois termos devem guardar outras conexões.

Na literatura pano alguns autores têm explorado a oposição entre xamãs e caçadores. Assim, Deshayes (1992) definiu o chefe kaxi como um hiper-caçador, antítese do xamã. Escrevendo sobre os Yaminawa, Townsley (1993, p.453-454) explorou a metáfora dos "caminhos", presente nos mitos e cantos, para opor especialistas xamânicos e caçadores. $\mathrm{O}$ autor descreve que atrás das casas, na aldeia, iniciam-se os caminhos largos e limpos em direção à floresta. Esses caminhos, quanto mais distantes da aldeia, tornam-se mais estreitos e cerrados. Neles os caçadores penetram à procura de suas presas, caminham tentando identificar todos os rastros, cheiros e sons. Finalmente, tentam atrair sua presa, imitando-a. Uma estratégia análoga é adotada pelos xamãs. Nas palavras do autor, "esta mímica, por intermédio da qual os humanos momentaneamente dominam o não-humano, tornando-se como ele, cria um campo de comunicação partilhado, que é precisamente este o objetivo do canto do xamã".

Observo que essas oposições, certamente válidas para os grupos em que foram propostas, não se devem confundir com o ponto para o qual tenho chamado atenção: a vinculação dos conhecimentos cinegéticos e xamânicos às grandes cobras, jibóias e anacondas. Aqui, a leitura que faço aproxima-se daquela que fez Calávia (2000). Analisando as "mitologias do cipó" entre os Kaxinawa, Yaminawa e Yawanawa, o autor observou como a ayahuasca, generalizadamente associada à cobra, não é um "fenômeno exclusivamente xamânico", vincula-se também a propósitos guerreiros e cinegéticos. Ao final, segundo o autor, "a cobra e o cipó se englobam reciprocamente e englobam o conjunto dos animais da floresta". A despeito do fato de que os mitos katukina que obtive em campo não agrupam diretamente, numa única narrativa, as cobras e o cipó, o exame de outros mitos e das concepções e práticas cinegéticas e xamânicas conduzem-me à mesma conclusão. 
Se aceita a interpretação de que os animais estão sob o controle das cobras, podemos correlacionar as atividades de xamãs e rezadores. Uma parte significativa dos problemas de saúde que afligem os Katukina é interpretada como tendo origem alimentar. As aflições do corpo são, em grande parte, resultado da quebra de resguardos alimentares. Os xamãs e rezadores ${ }^{6}$, responsáveis pelo restabelecimento dos doentes, adquirem seus conhecimentos por intermédio justamente das cobras e aprendem a debelar o espírito dos animais que afligem os doentes. Embora tenham que saber localizar a sua presa identificando todos os vestígios (rastros, cheiros e sons, principalmente), acabam, nos procedimentos de cura, atuando como caçadores às avessas, pois se o último tem de atrair a sua presa, o que os rezadores fazem é justamente espantá-la, ameaçando matar os bichos à faca ou com espingardas e também afogados, jogandoos nos igarapés. Os cantos de cura dos Katukina - e também dos ShipiboConibo (Illius, 1992), Yawanawa (Pérez, 1999) e Marubo (Montagner Melatti, 1985; Cesarino, 2008) - tematizam um confronto entre os rezadores e os espíritos (yushin) que provocam as doenças.

Fora do contexto da cura, os xamãs (mas não os rezadores) têm também a atribuição de atrair a caça para as proximidades da aldeia e o fazem entoando os cânticos de cura que lhes foram ensinados pelas cobras e viajando pacificamente por toda a geografia cósmica. Para isso, assumem a forma de animal, transmutando seu corpo para comunicarse além das fronteiras que lhe circunscreve a aparência humana. Os riscos envolvidos nessas viagens xamanísticas são justamente perder o controle, desfazer a paz imprescindível nestes encontros máximos de alteridade e render-se indeterminadamente à forma animal. Dois mitos (ver anexo) relatam a imprudência de alguns homens numa sessão de ayahuasca. O que as duas narrativas sugerem é que os especialistas xamânicos, no caso os bebedores de cipó, e caçadores não se devem confundir. Pode-se beber cipó para ver as caças que serão abatidas, mas ir à caça sob o efeito do cipó é, de princípio, uma temeridade.

Voltemos à correlação entre especialistas xamânicos e caçadores. Os xamãs, em suas viagens cósmicas, transmutam seus corpos, viram onças, macacos, queixadas; na água tomam a forma de surubins. A transmutação física, como observou Viveiros de Castro (1996, p.133) não deve ser compreendida, entretanto, como um disfarce ou fantasia, mas como meio de estabelecer a comunicação nesse campo intersubjetivo, para "ativar os poderes de um corpo outro". Já o caçador, em sua incursão pela mata, conta com seu próprio corpo, humano, e ativa seus poderes, entre outras coisas, com as injeções de kampô - substância que pode dissipar o 
rome do corpo dos xamãs e rezadores e que, por isso, é usada por eles apenas em pequena quantidade - e com o sumo de plantas pingadas em seus olhos, estimulantes cinegéticos que aguçam seus sentidos, a visão torna-se clara, a audição e o olfato apurados fazem-no seguir as pistas certas.

Caçadores e especialistas xamânicos atuam em diferentes horários: enquanto os primeiros vão à mata à procura de algum bicho com os primeiros raios de sol, os segundos iniciam suas atividades apenas depois que o sol se põe. A noite é dos espíritos (yushin), o que justifica o expediente invertido que ambos cumprem.

As oposições entre ambos não se encerram aí. Os processos de aquisição e produção de conhecimentos de xamãs e caçadores são também bastante distintos.

Os procedimentos de caça estão envoltos em cuidados e prescrições que, se efetivamente burlados, comprometem a carreira de um caçador. O aprendizado das estratégias de caça faz-se por longos anos, os garotos estão sempre interessados em ouvir os adultos contarem suas próprias façanhas. As primeiras tentativas de um garoto para abater um animal iniciam-se na tocaia. Além de esta estratégia envolver menos risco - no manejo da espingarda, por exemplo -, permite que o garoto observe de perto o hábito dos animais. Nas primeiras incursões de caça a curso, o garoto irá acompanhado do pai, de um irmão mais velho, ou de qualquer outro parente próximo, que deve orientá-lo na identificação dos muitos ruídos, odores e vestígios encontrados na floresta ${ }^{7}$. Para que a empresa da caça seja bem sucedida, os rapazes devem saber identificar cantos de certas aves que podem alertá-los da proximidade de certas presas. Assim, o canto da coruja chamada pupu (Otus colibba) anuncia a proximidade de porcos e o canto do cancão (Daptrius americanus) indica a proximidade de um bando de queixadas. Entretanto, ainda que o domínio de todos esses conhecimentos seja indispensável para qualquer candidato a caçador, é necessário também que se aprendam os cuidados que a interação com os animais requer. Quando abate a primeira presa, por exemplo, um rapaz não deve comê-la, sob o risco de tornar-se panema. Essa proibição é relaxada na medida em que consegue abater outros animais. Então, o rapaz passa a poder consumir a parte traseira do animal, recusando a dianteira. O caçador iniciante só poderá consumir livremente todos os animais após ter firmado o seu status abatendo uma determinada quantidade de presas. Uma carreira promissora de caçador pode se arruinar caso não sejam seguidas essas recomendações. Os bichos tor- 
nam-se ariscos e o caçador, apenas com as técnicas que domina, não consegue abatê-los.

Para livrar-se do panema (yupa), o melhor remédio, utilizado também nos cachorros, é a aplicação da secreção do sapo conhecido como kampô (Phyllomedusa bicolor), um estimulante cinegético ${ }^{8}$. Há quem diga, como Kako, que o panema pode ser também contornado com a ajuda das mulheres. Após sucessivas incursões de caça fracassadas, um homem pede, em segredo, a uma mulher para bater em suas costas, seja com suas próprias mãos ou com a parte lateral do terçado. A surra secreta, dada pela mãe, irmã, esposa ou amante, ajuda a afastar o panema. Além do kampô e das surras, uma certa dissimulação pode também render uma incursão mais proveitosa à floresta. Quando sai para caçar a curso, algumas vezes um homem despede-se anunciando que vai à mata, ea ni'i kai, não que vai abater um animal, visando assim iludir os animais, que podem ouvi-lo, sobre as verdadeiras intenções do caçador.

Um homem potencializa sua capacidade cinegética com o kampô e com o uso de colírios extraídos do sumo de plantas, eventualmente dissimula sua partida quando vai à floresta, familiariza-se desde cedo com o ciclo vegetal e animal, podendo assim localizar mais precisamente suas presas numa certa época. A combinação de todos esses elementos, e de outros, fazem da caça certamente uma atividade apreciada e prestigiosa. Mas se tantos requisitos e propriedades são requeridos ao caçador, é justamente porque a empresa da caça não é das mais fáceis e não é desprovida do que se poderia chamar igualmente de conhecimento xamânico. Expondo-se na floresta, por trilhas cerradas e habitadas por seres que, ao menos em aparência, não são seus semelhantes, o caçador arrisca-se também.

Se, na cidade ou nas visitas às aldeias de grupos indígenas vizinhos os Katukina sentem medo e portam-se com precaução, tanto mais na mata, onde se está diante de uma alteridade mais radical. Perder-se na mata, embora não seja uma possibilidade levada muito a sério desde que se more no local há muito tempo - e que se conheça, então, o meio em que se desloca -, pode acontecer se o caçador encontrar uma jabota ovada e passar a mão sobre a malha de seu casco. Assim como o desenho do casco da jabota é labiríntico, o caçador ficará andando pela floresta e retornando sempre ao mesmo lugar. Nessa situação, o melhor é não passar a mão na jabota ou então pegá-la e levá-la consigo. O risco de perder-se não é tanto demorar a encontrar o caminho certo, mas sim demorar-se nessa tentativa e ver a noite chegar dentro da mata. Poucos 
homens arriscam-se em caçadas noturnas, se o fazem estão acompanhados de algum parceiro, parente ou amigo. Mesmo assim, essa possibilidade é considerada apenas excepcionalmente.

Ao voltar da mata, um rapaz reclamou comigo, com muita raiva, que os brancos estavam invadindo as suas terras para caçar durante a noite. Ele, que havia voltado frustrado da mata, sem ter matado qualquer bicho, queixou-se: “a gente, Katukina, não caça durante a noite que é para não faltar caça, os brancos caçam com lanterna que deixa os bichos mansinhos, e acabam com tudo". Ouvi esse argumento ecológico uma única vez. Com mais freqüência as pessoas comentam dos riscos da caça noturna, dos sons que são ouvidos na mata, sem que se saiba de onde vêm e que podem atrair o caçador e fazê-lo arriscar a sua própria vida caso sejam respondidos - uma visada perspectivista está aqui presente.

Se o processo para tornar-se caçador é bastante público - e não faltam comentários elogiosos ou jocosos sobre os sucessos ou fracassos alheios -, passa-se tudo diferentemente no que diz respeito aos especialistas xamânicos. Seja para tornar-se um romeya (xamã) ou um shoitiya (rezador/curador), um homem deve encontrar uma cobra que lhe revela os segredos da cura. Caçando, a caminho de casa ou mariscando, a cobra aparece no caminho de um homem, que sente estranhas sensações em seu corpo - mudança de cheiro (o corpo cheira a cobra), turvamento da visão, tonturas e calafrios. Estes encontros com as cobras são interpretados como eleição, uma indicação de que a pessoa foi escolhida para deter os conhecimentos de cura. O tamanho da cobra (muito grande/ grande) parece determinar a quantidade de segredos que pode revelar e se o homem poderá atuar como xamã ou rezador.

A precariedade e provisoriedade da vida katukina é contornada pelos xamãs e rezadores que obtêm parte de seus conhecimentos de cura por intermédio das cobras, detentores do rome e, por isso, imortais.

A tradução de rome como "pedra" é feita livremente pelos Katukina, mas apenas para remeter à dureza ou à solidez, pois a pedra propriamente dita é designada por shoko. Entretanto, no vernáculo, rome sugere pistas interessantes, pois esta palavra é usada também para designar o tabaco, que é a principal substância utilizada nos ritos de cura e romeya (com o tabaco/"pedra") designa o xamã.

Aqui, abro um parêntese para tratar de questões lingüísticas. A etimologia de rome exposta acima, ainda que adequada e aceita pelos próprios Katukina, pode ter outras derivações. Vejamos. As cobras têm rome e por isso são portadoras dos conhecimentos xamânicos. Mas são 
portadoras destes saberes por que obtiveram o shoko nane, a "pedrajenipapo", que lhes proporcionou a vida eterna. O rome e o shoko nane confundem-se, e essa confusão só se desfaz voltando os olhos a outros grupos pano. Existe a possibilidade de que a tradução de rome como "pedra" possa ser tomada ao pé da letra.

Em seu trabalho sobre o xamanismo yawanawa, Pérez (1999, p.154) informa que, em determinadas rezas, alguns "seres-aliados" são invocados para combater a doença e aparecem como o "velho do machado de pedra", ruweya sheneki. Neste caso, ruwe designa o machado de pedra. A mesma autora afirma que a pedra é um elemento de poder e nas rezas yawanawa são feitas alusões ao machado de pedra - trata-se de uma arma para combater as doenças. ${ }^{9}$ Entre os Matis, dwë designa atualmente o terçado e shotko é o termo usado para o machado. Nem sempre foi assim. Segundo Philippe Erikson (comunicação pessoal), dwë era usado primeiramente para o machado de pedra, passou depois a designar o machado de ferro, mais tarde o de metal e é, nos dias de hoje, o termo reservado ao terçado. Os próprios Katukina designam o machado de pedra como roe. Os termos para machado de pedra dos Katukina - roe e aquele dos Matis - dwë - apresentam ligeiras diferenças fonéticas. As semelhanças entre o roe e o shoko dos Katukina e o dwë e o shotko dos Matis são um tanto evidentes. Feitas essas considerações, penso que talvez seja possível supor que o rome dos Katukina, que atualmente designa o tabaco, seja um termo anteriormente utilizado para o machado de pedra ${ }^{10}$. Esta possibilidade, apenas ensaiada rapidamente aqui, parecerá mais plausível se não nos esquecermos de que, entre os Yawanawa, o machado de pedra (ruwe) é sempre mencionado, nas rezas, como uma arma. Tanto mais porque os ritos de cura executados pelos Katukina e por outros grupos pano como se verá adiante, são concebidos como um embate entre os especialistas xamânicos e seres sobrenaturais.

Retornando à iniciação xamânica, as alterações sensoriais - olfato e visão, principalmente - diante de uma grande serpente seriam indicativos de que ela "jogou" o rome em um homem e o rome penetrou em seu corpo, o que o capacita, de alguma maneira, a estabelecer relações sobrenaturais. Os xamãs teriam rome em grandes quantidades, o que não só explica a tradução de sua designação vernácula como sua superioridade em relação aos rezadores, que o têm em menor quantidade. Os antigos xamãs são lembrados por terem muito rome e pelo fato de poderem retirá-los e colocá-los em seus próprios corpos a qualquer momento, exibindo suas habilidades diante de uma platéia aturdida. 
A permanência do rome no corpo, entretanto, não é definitiva, deve ser garantida com uma rotina sem sobressaltos e uma dieta alimentar. No que diz respeito à rotina, a principal precaução a ser tomada é evitar sustos, emoções repentinas. Ocorrências tão banais como o latido inesperado de um cachorro ou mesmo o grito de uma criança podem dissipar o rome. Quanto à dieta, os aprendizes e também os rezadores experientes devem evitar os alimentos doces (vata), como mel, açúcar, mamão, abacaxi, cana-de-açúcar e algumas qualidades de banana. ${ }^{11} \mathrm{O}$ caranguejo (shanka), igualmente, deve ser evitado, devido ao sabor e ao cheiro adocicados. Tempos atrás, lado a lado da evitação de alimentos doces estava a proscrição de consumir pimenta. A dieta dos xamãs é mais rigorosa e, além de prever com mais convicção a abstenção de alimentos doces, supõe a restrição de relações sexuais.

Rezadores e xamãs, diferentemente dos outros homens, não fazem aplicação de kampô, o estimulante cinegético, ou o fazem com menos freqüência e em menor quantidade. Como em outros grupos amazônicos, os especialistas em assuntos xamânicos são algo panema. Quando rezadores usam o kampô, aplicam-no apenas em pequenas quantidades (no máximo fazem cinco aplicações), a fim de eliminar algum mal-estar físico. O kampô, do mesmo modo como os alimentos doces, podem dissipar o rome.

A eleição ao xamanismo independe do desejo ou da aspiração dos indivíduos, uma vez que o contato sobrenatural, nesta etapa, não é uma prerrogativa do desejo ou da decisão voluntária do indivíduo. Após o encontro com a cobra, um homem passa a ter sonhos de revelação, os segredos de cura são aprendidos. Os rezadores com os quais pude discutir estes assuntos disseram-me que sonharam com um homem que lhes oferecia ayahuasca ou rapé para consumirem juntos. Em seguida, este homem dava-lhes uma mulher com a qual se uniam e que, desde então, sempre os acompanhava, ensinando-lhes a identificar as doenças e suas respectivas curas. Alguns dos rezadores identificam claramente Rono Yushin como uma "esposa".

Uniões de especialistas xamânicas com mulheres-espíritos foram já registradas na literatura pano. Saladin d'Anglure e Morin (1998) escreveram um artigo sobre o "casamento místico" entre xamãs e espíritos entre os Shipibo-Conibo. Segundo os autores, uma parte significativa das abstinências que um xamã tem de observar, particularmente a sexual, deve-se aos ciúmes da esposa onírica. Dessa união os xamãs têm também filhos oníricos. Entre os grupos de língua pano, o primeiro registro dessas 
uniões foi feita por Montagner Melatti (1985, p.409-410) entre os Marubo. A autora escreveu que, neste grupo, do relacionamento íntimo entre os xamãs e os yobe (espíritos benevolentes), os primeiros podem vir a constituir uma "família espiritual". Nos resumos biográficos que ofereceu dos especialistas xamânicos, consta o caso de um xamã, Tomás, que selou seu casamento místico quando tinha apenas 18 anos. Sua esposa mística auxiliava-o nos ritos de cura e acompanhava-o nas viagens extáticas. Dessa união o casal gerou um filho. $\mathrm{O}$ xamã Tomás teria se reunido à sua família mística após sua morte. À diferença dos Katukina e dos Marubo, o "casamento místico" na concepção dos Shipibo-Conibo marca não o princípio, mas o resultado de um "longo processo de preparação e aprendizagem" (Saladin d'Anglure e Morin 1998, p.56).

Voltando à eleição xamânica entre os Katukina, no primeiro sonho, em um cenário de trevas, os atuais rezadores dizem ter visto muitos doentes: pessoas prostradas nas redes, com febre, diarréia, tremores, tosse, vômitos. A mulher, encarnação do rono yushin (espírito da serpente), ensinava-lhes então as palavras mágicas que deveriam ser ditas e que eles passavam a repetir uma a uma. Pouco tempo depois, os doentes estavam bons: sentavam-se, bebiam água, comiam, penteavam os cabelos - o que indicava que já estavam curados.

Um sonho como este sela definitivamente a eleição para tornar-se um shoitiya. A partir de então, o homem procura um rezador mais experiente que possa iniciá-lo nos segredos e na prática das rezas, além de passar a consumir quantidades maiores de rapé que estimulam novos sonhos com o "espírito da serpente", com o qual deve aprender novas rezas.

Não há qualquer problema em recusar a carreira xamânica, em declinar o chamado de rono yushin, mas aqueles que a atacam são punidos. Os Katukina não matam jibóias (mana rono), sucuris e outras cobras de grande porte, pois acreditam que, se assim fizerem, terão de volta a vingança da cobra morta que lhes poderá causar a morte ou deficiências físicas irreversíveis. Contrariamente, então, a outros grupos pano - como os Sharanawa (Siskind, 1973a, p.165-166), os Yaminawa (Townsley, 1988, p.133 e Calávia Saez, 1995, p.107-108), os Kaxinawa (Lagrou, 1998, p.76) e os Yawanawa (Pérez, 1999) -, que, para obter os poderes das grandes cobras, matam-nas e também comem partes de seu corpo. ${ }^{12}$

Aqueles que aceitam de bom-grado o contato sobrenatural e desejam mesmo seguir uma carreira de rezador, devem aprofundar seus conhecimentos, seja solitariamente ou com a ajuda de rezadores mais 
experientes ou ambas as formas ao mesmo tempo, como é mais comum. Se, solitariamente, um homem passa a consumir rapé todas as noites, a fim de estimular a ocorrência de sonhos com Rono Yushin, o espírito da serpente, que o instrui sobre as doenças e os cantos de cura. Na companhia de um rezador mais experiente, o aprendiz consome também rapé e, algumas vezes, ayahuasca, e aprende com ele os cantos apropriados para cada doença e também os sintomas que devem ser observados nos pacientes. De uma maneira mais informal, um aprendiz pode também acompanhar um rezador mais experiente sempre que for consultar um paciente. Assim, o aprendiz, na sessão de cura, posta-se ao lado do rezador e ouve atentamente seus cantos de cura. Após acompanhar seu instrutor várias vezes, ele passa também a participar, entoando o mesmo canto ao mesmo tempo.

O processo para tornar-se um xamã segue quase que paralelo ao do rezador. Entretanto, não é qualquer cobra grande que faz de um homem um xamã, apenas duas: vino rono e teshoika (que não pude identificar), as maiores moradoras das profundezas das águas. Além disso, tendo encontrado a cobra e recebido o rome, um homem não precisa acompanhar um outro xamã experiente para instruí-lo, o conhecimento todo lhe é transmitido por Rono Yushin de uma só vez, poupando-lhe longos períodos de aprendizado. Entre os xamãs fala-se menos em aprendizado e mais em treinamento. Com o consumo de ayahuasca e rapé e observando as restrições alimentares e sexuais, um homem consegue manter o rome ativo em seu corpo, sem precisar receber qualquer outra instrução.

É previsto também que os shoitiya façam uso de ayahuasca para estimular as visões, os encontros com Rono Yushin, mas o mais comum é o uso do rapé (rome poto, "pó de tabaco"). O uso que os Katukina fazem da ayahuasca atualmente parece-me sensivelmente inferior ao que fazem outros grupos pano, em particular, os Shipibo-Conibo (Árevalo Valera, 1986; Illius, 1992), os Kaxinawa (Kensinger, 1995a), os Yaminawa (Calávia Saez 1995) e os Yawanawa (Pérez, 1999). Pelas inúmeras conversas que tive com os Katukina, suspeito que as beberagens de cipó foram maiores no passado, especialmente em um período em que havia cinco romeya em atividade ao mesmo tempo, há quase 30 anos. De todo modo, o pouco uso de ayahuasca não é exclusividade dos Katukina e na literatura pano consta mesmo que certos grupos não o usavam. Este é o caso dos Uni que, de acordo com Frank (1994, p. 202), tradicionalmente não bebiam ayahuasca, passaram a fazê-lo há pouco tempo, após alguns homens terem recebido treinamento xamânico com seus vizinhos, os Shipibo-Conibo. 
Por toda área pano, segundo Erikson (1993, p.48), o tabaco é mais usado como alucinógeno xamânico do que a ayahuasca. Essa preferência pelo tabaco aplica-se estritamente aos Katukina. Os rezadores são todos tabagistas contumazes e não aguentam muitas horas sem rapé ou cigarro.

\section{Anotações finais: partilha de conhecimentos?}

Finalmente, caçadores e especialistas xamânicos podem ser reaproximados quando se trata da forma como é concebida a acumulação e transmissão de seus conhecimentos ${ }^{13}$. Seja xamã ou caçador, os conhecimentos não devem ser partilhados precocemente. No caso dos caçadores, os conhecimentos sobre as técnicas e o ambiente são públicos, não envolvem maior segredo. No entanto, deve ser destacado que a aplicação do kampô, capaz de aguçar suas capacidades cinegéticas, deve ser feita por um caçador bem sucedido em sua carreira, como se ele pudesse transferir para o outro, sem maiores prejuízos, as potências (pelo termo pretendo resumir os próprios conhecimentos, a habilidade e a 'sorte' do caçador maduro) acumuladas em seu corpo. Um caçador maduro é propriamente um caçador velho, que não dispõe mais de vigor físico para aventurar-se pela mata e não tem, por isso, prejuízos em partilhar as potências que acumulou em seu corpo ao longo da vida. Pela mesma razão, mas contrariamente, jovens rapazes não devem precocemente partilhar suas potências, sob o risco de exporem e perderem sua própria sorte. Igualmente se passa entre os especialistas xamânicos, que são frequentemente avessos a iniciar um aprendiz (e, por isso, acusados de mesquinhez), com o argumento de que a transmissão de seus conhecimentos pode fazê-los perder seus próprios conhecimentos. Tudo se passa como se fosse melhor falar aqui propriamente de uma "transferência" de conhecimento e não de uma "transmissão".

As palavras repetidas nos cantos de cura não só veiculariam o poder xamânico, mas seriam elas próprias fontes primeiras de poder. A partilha delas com outros poderia resultar na despotencialização das palavras de seu possuidor. Essas palavras restariam então sob o controle daquele que as "recebeu". Estariam habilitados a transmitir os conhecimentos xamânicos, sem risco de perda de poder, apenas rezadores bastante experimentados, que já sedimentaram seus conhecimentos.

Nos dois casos, a partilha dos conhecimentos, sejam cinegéticos sejam xamânicos, envolvem considerar também o ciclo de vida, pois os homens podem começar (e começam, de fato) a dedicarem-se às rezas e 
curas bem mais tarde do que se iniciam na caça; e a sedimentação desses conhecimentos só seria efetiva, então, quando estão bastante velhos. Nesse sentido, é importante dizer que não constituem exceção os homens que foram, na juventude, caçadores aplicados ou bem-sucedidos e que, transcorrido um longo tempo, tornaram-se rezadores dedicados ${ }^{14}$.

É bem verdade que, nos dias de hoje, os Katukina não contam mais com xamãs poderosos nem com caçadores extremamente aplicados ${ }^{15}$, os atuais não são comparáveis à qualidade e quantidade deles que havia no passado - pelo menos é isso o que se comenta. Seja como for, contrapor os cuidados e formas de conduta ideais que ambos têm de adotar ajuda a pôr em relevo a posição que cada um deles ocupa, compreendendo-as ainda como contraditórias, mas vinculadas à mesma esfera de conhecimento, controlada pelas cobras. Se os animais silvestres aparecem aos olhos da jibóia como "mansos", é porque ela controla tanto o sucesso do caçador quanto dos especialistas xamânicos que, seja nas sessões de cura seja tentando fazer a caça farta, estão lidando com seres que estão sob o seu próprio domínio.

\section{Anexos - Mitos}

\section{Mito 1}

Tinha um pajé (romeya) que estava tomando cipó, dizendo que ino yawa (uma queixada valente, que come gente) ${ }^{16}$ já estava perto. Um outro homem disse:

- Ah! Pode vir, pode vir que a gente resolve.

Romeya disse:

- Tu não resolve nada...

O homem insistiu:

- Resolvo. Se você é um romeya mesmo, pode trazer a queixada pra cá que a gente resolve.

Aí romeya tomou cipó de novo e viu que ino yawa já estava perto. O homem dizia:

- Pode trazer pra cá que a gente resolve. Deixa comigo que eu resolvo.

Romeya disse:

- Tu não resolve nada...

O cunhado deste homem disse ao romeya:

- Não, não traz a ino yawa pra cá, deixa ela voltar pra lá de novo.

O homem insistia:

- Traz pra cá! Traz pra cá que a gente resolve.

No outro dia, eles foram tomar cipó de novo. Ele falava do mesmo jeito. $\mathrm{O}$ cunhado dele, com raiva dele, achava que ele estava mentindo. $\mathrm{O}$ 
romeya disse, de novo:

- Amanhã de manhã você vai lá espiar ino yawa, ver como ino yawa (os queixadas) vêm.

Ele disse:

- Ah! Eu vou espiar lá, pra ver se é verdade mesmo.

Eles saíram, estava ainda escuro. Quando deu 7 horas da manhã o homem que desafiou o pajé estava morto de cansado e ino yawa já estava perto. O homem falou pro romeya que o acompanhava:

- Ino yawa já vem mesmo romeya e agora, como a gente faz?

O romeya respondeu:

- Resolve, que você estava dizendo que resolvia.

Aí ele, a família dele mais a família do cunhado dele subiram numa samaúma grande que estava caída. Ele estava com um cipó na mão e subiram. $O$ cunhado do homem valente perguntava para o romeya:

- E agora romeya, como a gente faz?

- Não, agora tem que resolver com ino yawa.

Ino yawa derrubou as casas, tudo, comeu tudinho. Só ficou a família dele e a família do cunhado dele. Quando acabou de comer essa gente tudinho, os ino yawa voltaram pra mata de novo e os três acompanharam ino yawa: o homem valente, o cunhado dele e o romeya. Foram embora, ninguém sabe pra onde eles foram, parece que viraram ino yawa também.

Mito 2

Um homem estava tomando cipó (oni). Enquanto isso, o cunhado dele foi atrás de queixada, o cunhado dele matou não sei nem quantas queixadas. Então, o cunhado chegou e ele disse:

- Tu já veio cunhado?

- Já vim. Eu já matei as queixadas, eu vou juntar tudinho para nós levarmos esses bichos que eu matei. Você pode esperar aí que eu vou juntar a queixada tudinho.

Enquanto isso, o cunhado ficou juntando a queixada que ele matou e ele não esperou. Chegou um outro homem que estava também caçando com o cunhado dele e disse:

- Ah! Nós matamos queixada, nós não matamos mais queixada porque você não deixa a mulher, tem saudade da mulher e não foi caçar com a gente.

Ele ficou com raiva do outro e falou para a mulher dele:

- Mulher, eu vou para o lado que o bando da queixada foi, eu vou espiar, você espera por aqui mesmo que eu venho logo.

Então, ele saiu sozinho. Pegou a flecha, o cachorro e saiu. O cunhado dele chegou e perguntou dele:

- Cadê o cunhado?

A mulher disse que ele tinha saído. Ele disse para a irmã dele:

- Mas eu falei pro seu marido esperar aqui para a gente levar as queixadas. 
Então ele saiu atrás de seu cunhado. O cunhado dele foi, gritou, mas ele escondeu, escondeu no mato. A flecha dele estava quebrada e ele deixou no canto. O cunhado dele foi atrás e gritou, gritou, gritou. Ele não respondia nada, nada, nada. O cunhado dele resolveu voltar. No outro dia o cunhado dele foi atrás dele de novo.

No outro dia o cunhado dele foi atrás de novo, gritava e não respondia. E foi, foi, rastejando a queixada todo o tempo. Onde a queixada dormia, ele dormia também no toco do pau. O cunhado dele gritou, gritou, gritou e ele não respondia nada. Isto porque ele foi embora, virou queixada. Hoje em dia ele ainda está com os queixadas. Estes tempos que eu fui matar queixada, eu vi ele. $\mathrm{O}$ cachorro que viu. $\mathrm{O}$ nome dele é Panan. Ele é o chefe das queixadas.

\section{Notas:}

${ }^{1}$ Os Katukina somavam, em 2007, uma população de aproximadamente 550 pessoas, distribuídas em duas Terras Indígenas: do rio Campinas e do rio Gregório, localizadas no Acre. Entre 1991 e 2000 fiz 18 meses de trabalho de campo (que resultaram em meus trabalhos de mestrado e doutorado, ver Lima, 1994 e 2000). Na maior parte desse tempo estive entre os Katukina da TI do rio Campinas. Desde 2005 retomei o trabalho de campo, embora tenha feito temporadas mais breves.

${ }^{2}$ Não quero dizer com isso que essa labilidade não seja mais existente, mas o contexto histórico-político dos últimos anos, penso, particularmente a partir do início (no Acre, ao menos) da demarcação das terras indígenas até os dias de hoje, sugere um movimento em direção da cristalização dessas fronteiras, seja em seu sentido "territorial" seja em seu sentido "cultural" - um tema bastante interessante, mas que não poderei aqui desenvolver.

${ }^{3}$ Os Katukina diferenciam seus especialistas xamânicos: existem aqueles que eles traduzem como rezadores (shoitiya) e pajés (romeya). Para maiores detalhes sobre a atuação de ambos, ver Lima (2000).

${ }^{4}$ Entre os seringueiros da região do alto Juruá, possivelmente por influência dos vários nawa (como são também conhecidos os grupos de língua pano) que os rodeiam, olhos de jibóias são usados como amuleto para atrair animais de caça, dinheiro e mulheres (Araújo, 1998, p. 83-84).

${ }^{5}$ As inversões envolvem também certas práticas que não se relacionam às cobras. Assim, os Yaminawa aspirantes a xamã submetem-se às picadas das formigas chamadas ani (Townsley 1988, p.133), uma prova dolorosa à qual os homens katukina, no passado, passavam para ter sorte no abate das aves.

${ }^{6}$ Entendo que uma concepção ampla de xamanismo não se deve restringir apenas ao tratamento dos problemas de saúde, como se este fosse direcionado exclusivamente à cura e construído a partir da existência de especialistas. Se essa é a faceta que mais aparece aqui, é porque foram esses os caminhos que me indicaram os próprios Katukina. Como se verá adiante, a caça mesma não está desprovida de intervenções que poderiam ser chamadas e entendidas como "xamânicas", na me- 
dida em que pressupõem também a existência de diversas técnicas e conhecimentos para lidar com o entorno sócio-cosmológico (Langdon, 1996).

${ }^{7}$ Atualmente, as estratégias de caça são apenas essas duas: a tocaia e a caça a curso, com ou sem cachorro. Outrora, segundo o falecido Tsomi, os Katukina usavam também armadilhas: cavavam buracos de dois ou três metros de profundidade, nas veredas em que passavam os animais, e fincavam no fundo estacas afiadas, feitas de pupunha ou cana-brava. Por cima tapavam o buraco com galhos e folhas, para que os bichos não percebessem a existência da armadilha e desviassem o caminho. Com o mesmo fim, toda a terra retirada do buraco era removida do local. Essa estratégia envolvia pouco risco, tendo o bicho caído na armadilha, bastava retirá-lo. Entre os Uni, Frank (1994, p.169) oferece uma descrição idêntica de armadilha de caça.

${ }^{8}$ Desde o final da última década, o uso do kampô começou a difundir-se entre populações do meio urbano - regionalmente, como em Cruzeiro do Sul e Rio Branco, e também em grandes cidades do país, como em Belo Horizonte e São Paulo. Em grande parte, essa difusão se faz por intermédio de membros de religiões ayahuasqueiras, como o Santo Daime e a União do Vegetal (UDV). Em outros trabalhos tratei da repercussão da popularização do kampô e sua aproximação do xamanismo new age no meio urbano entre os Katukina e outros grupos indígenas da região do alto Juruá (ver Lima, 2005 e 2008). Para conhecer os usos urbanos que estão fazendo da substância, vista por muitos agora como uma "planta de poder", ver Lima e Labate (2007).

${ }^{9}$ Cabe destacar que, segundo Pérez (1999, p.154 e 192), os Yawanawa fazem menção à quentura da pedra e, por isso, chegam a chamá-la de "machado de fogo". Diferentemente então dos Katukina que sempre destacavam a dureza quando falavam do rome. Na concepção dos Katukina, os raios são pedras (shoko) que caem do céu. Assim, o tema da quentura está de algum modo também presente.

${ }^{10}$ Agradeço a Philippe Erikson por ter chamado minha atenção para esta hipótese.

${ }^{11}$ Em vários grupos pano o sabor amargo aparece relacionado ao poder xamânico. Entre os Kaxinawa os xamãs são chamados de huni mukaya ("homem que tem amargor") (Kensinger, 1995, p.213-218). Erikson (1996, p.203 e ss) observou que a maior parte das substâncias usadas no contexto místico deixam um gosto amargo na boca, como a ayahuasca e o tabaco. Entre os Matis, a oposição bata (doce)/chimu (amargo) excede o contexto xamânico e todos os homens evitam alimentos doces, enquanto procuram ingerir os amargos.

${ }^{12}$ De todo modo, mesmo em grupos nos quais é corrente a prática de matar a cobra para obter seus conhecimentos, sejam esses relacionados à caça ou ao xamanismo, não está excluída a possibilidade de vingança em algumas situações. Deshayes (1992, p.104 e 2000, p.33) relatou o caso de um homem que, à beira de um lago, foi mordido várias vezes por uma anaconda, mas que conseguiu defender-se golpeando-a com uma faca e matando-a. A anaconda é áglifa, não consegue inocular seu veneno. Apesar disso o homem que a matou delirou toda a noite, sonhava que várias cobras o perseguiam a fim de afogá-lo no lago. 
${ }^{13}$ Essa passagem altera de modo significativo o que foi registrado em minha tese de doutorado, ver Lima (2000)

${ }^{14}$ Em minha tese de doutorado (Lima, 2000, p.132-133), apresento o relato de Mekon, que teve um encontro com uma cobra, interpretado como um "chamado xamânico", durante uma incursão à caça.

${ }^{15}$ No que diz respeito à caça, devo pontuar que, desde o início de 2000, as condições do estoque faunístico se alteraram significativamente na TI do rio Campinas, devido ao asfaltamento da BR-364 (no trecho entre Rio Branco e Cruzeiro do Sul). Há, desde então, um flagrante decréscimo de animais de caça que pode ser o resultado concomitante do tráfego de veículos que circulam agora diariamente pela rodovia e da migração de moradores da TI do rio Gregório para lá, que devem certamente ter contribuído para pressionar a fauna local (ver Lima, 2006) - isso para não falar das frequentes invasões de caçadores vizinhos para caçar na mesma área.

${ }^{16}$ Ino é o termo com o qual os Katukina denominam as onças miticamente e yawa designa a queixada. Numa tradução literal teríamos então a "queixada-onça", destacando assim o potencial agressivo e predador dessa "espécie" de queixada.

\section{Referências}

AQUINO, Terri V.; IGLESIAS, Marcelo P. Kaxinawá do rio Jordão. História, território, economia e desenvolvimento sustentado. Rio Branco: Comissão Pró-Índio (AC), 1994.

ARAÚJO, Gabriela. Entre almas, encantes e cipó. 1998. Dissertação (Mestrado em Antropologia Social) - PPGAS/UNICAMP, Campinas.

ARÉVALO VALERA, G. El ayahuasca y el curandero Shipibo-Conibo del Ucayali (Perú), América Indígena, México, n.XLVI, p.147-161, 1986.

CALÁVIA, Oscar. O nome e o tempo dos Yaminawa. 1995. Tese (Doutorado em Antropologia Social) - PPGAS/USP, São Paulo.

. Mythologies of the vine. In: LUNA, Luis Eduardo; WHITE, Steven F. (eds.). Ayahuasca Reader. Encounters with the Amazon's Sacred Vine. Santa Fé: Synergetic Press, 2000. p. 36-40.

CARID, Miguel A. Yawanawa: da guerra à festa. 1999. Dissertação (Mestrado em Antropologia Social) - PPGAS/UFSC, Florianópolis.

CARNEIRO, Robert. The Amahuaca and the Spirit World. Ethnology, n. 3, p. 6-11, 1964.

. Hunting and hunting magic among the Amahuaca indians of the peruvian montaña. Ethnology, IX : 331-341, 1970.

CESARINO, Pedro N. Oniska. A poética da morte e do mundo entre os Marubo da Amazônia Ocidental. 2008. Tese (Doutorado em Antropologia Social) - PPGAS/ MN, UFRJ, Rio de Janeiro.

CPI-AC. Shenipabu Miyui. História dos Antigos. Rio Branco: Comissão Pró-Índio, 1995. 
DESHAYES, Patrick. Paroles chassées. Chamanisme et chefferie chez les Kashinawa. Journal de la Société des Américanistes, Paris, n. LXXVIII, v. 2, p. 95-106, 1992.

. Les mots, les images et leurs maladies chez les indiens Huni Kuin de l'Amazonie.

Paris: Éditions Loris Talmart, 2000.

DRUMMOND, Louis. The serpent's children: semiotics of cultural genesis en Arawak and Trobriand myth. American Ethnologist, n. 8, v. 3, p. 633-660, 1981.

ERIKSON, Philippe. Alterité, tatouage et anthropophagie chez les Pano: la belliqueuse quête du soi. Journal de la Société des Américanistes, Paris, n. LVII, p. 185210, 1986.

Une nébuleuse compacte: le macro-ensemble pano. L'Homme, Paris, n. XXXIII, v. 2/4, p. 45-58, 1993.

. La griffe des aïeux. Marquage du corps et démarquages ethniques chez les Matis d'Amazonie. Paris: CNRS/Peeters, 1996.

Myth and Material Culture: Matis Blowguns, Palm Trees, and Ancestor Spirits. In: RIVAL, Laura; WHITEHEAD, Neil (eds.). Beyond the Visible and the Material: the Amerindianization of Society in the Work of Peter Rivière. Oxford: Oxford University Press, 2001. p. 101-121.

FRANK, Erwin H. Los Uni. In: SANTOS, Fernando; BARCLAY, Frederica (eds.). Guía Etnográfica de la Alta Amazônia. Quito: Flacso/IFEA, 1994. v. 2.

ILLIUS, Bruno. The concept of nihue among the Shipibo-Conibo of Eastern Peru. In; LANGDON, Esther Jean; BAER, Gerhard (eds.). Portals of power. Shamanism in South America. Albuquerque: University of New Mexico Press, 1992. p. 63-77.

KENSINGER, Kenneth. How real people ought to live. The Cashinahua of eastern Peru. Illinois: Waveland Press, 1995.

LAGROU, Elsje. Xamanismo e representação entre os Kaxinawá. In: LANGDON, Esther Jean (org.). Xamanismo no Brasil. Novas perspectivas. Florianópolis: UFSC, 1996. p. 197-231.

. Caminhos, duplos e corpos. Uma abordagem perspectivista da identidade e alteridade entre os Kaxinawa. 1998. Tese (Doutorado em Antropologia Social) PPGAS/USP, São Paulo.

LANGDON, Esther Jean. Introdução. In: perspectivas. Florianópolis: UFSC, 1996. (org.). Xamanismo no Brasil. Novas

LIMA, Edilene C. Katukina: história e organização social de um grupo pano do alto Juruá. 1994. Dissertação (Mestrado em Antropologia Social) - PPGAS/USP, São Paulo.

. Com a pedra da serpente. 2000. Tese (Doutorado em Antropologia Social) PPGAS/USP, São Paulo.

Kampu, kampo, kambô: o uso do sapo-verde entre os Katukina. Revista do IPHAN, Rio de Janeiro, n. 32, p. 254-267, 2005.

. BR-364 e os Katukina: a história se repete. In: RICARDO, Beto; RICARDO, Fany (Orgs.). Povos indígenas no Brasil 2001-2005. São Paulo: Instituto Socioambiental, 2006. p. 586-587. 
As novas formas do kampô: elementos para uma sociologia da disseminação urbana dos saberes nativos. In: LENAERTS, Marc; SPADAFORA, Ana María. Pueblos indígenas, plantas y mercados. Bucharest: Zeta Books, 2008. p. 169-197.

LIMA, Edilene C.; LABATE, Beatriz C. Remédio da ciência'e 'remédio da alma': os usos da secreção do kambô (Phyllomedusa bicolor) nas cidades. Campos - Revista de Antropologia Social, Curitiba, n. 8, v. 1, p. 71-90, 2007.

MONTAGNER MELATTI, Delvair. O mundo dos espíritos: estudo etnográfico dos ritos de cura Marubo. 1985. Tese (Doutorado em Antropologia Social) - PPGAS/ UnB, Brasília.

MONTAGNER, Delvair. Cânticos xamânicos dos Marubo. In: LANGDON, Esther Jean (org.). Xamanismo no Brasil. Novas perspectivas. Florianópolis: UFSC, 1996a. p. 171-195.

. A morada das almas. Representações das doenças e das terapêuticas entre os Marubo. Belém: Museu Paraense Emílio Goeldi, 1996b. (Coleção Eduardo Galvão). MUNDKUR, Balaji. The cult of serpent in the Americas. Current Anthropology, n.17, p. 429-441, 446-455, 1976.

PÉREZ, Laura. Pelos caminhos de Yuve: conhecimento, cura e poder no xamanismo yawanawa. 1999. Dissertação (Mestrado em Antropologia Social) - PPGAS/UFSC, Florianópolis.

SALADIN D'ANGLURE, Bernard;MORIN, Françoise. Mariage mystique et pouvoir chamanique chez les Shipibo d'Amazonie péruvienne et les Inuit du Nunavut canadien. Anthropologie et Sociétés, Quebéc, n. 22, v. 2, p. 49-74, 1998.

TASTEVIN, Constantin. Le Haut-Tarauaca. La Géographie, n. XLV:34-54; 158-175, 1926.

TOWNSLEY, Graham. Ideas of order and patterns of change in Yaminahua Society. 1988. Tese (Doutorado em Antropologia Social) - Cambridge University, Cambridg..

Songs paths. The ways and means of shamanic knowledge. L'Homme, Paris, n. XXXIII, v. 2/4, p. 449-468, 1993.

VIVEIROS DE CASTRO, Eduardo. Os pronomes cosmológicos e o perspectivismo ameríndio. Mana, Rio de Janeiro, n. 2, v. 2, p. 115-144, 1996.

Recebido em 15 de julho de 2008.

Aprovado para publicação em 29 de julho de 2008.

Tellus, ano 8, n. 15, jul./dez. 2008 
